\title{
The Efficacies of an Explicit Vocabulary Instruction Model on ESL Learners' Vocabulary Size and Writing Skills
}

\author{
Frankie Subon ${ }^{1}$, Norseha Unin ${ }^{2}$ \\ ${ }^{1}$ Management and Science University \\ ${ }^{2}$ Universiti Teknologi MARA Cawangan Sarawak
}

\begin{abstract}
Correspondence concerning this article should be addressed to Dr. Frankie Subon, School of Education and Social Sciences, Management and Science University, 40100 Shah Alam, Malaysia.

E-mail: frankie_subon@msu.edu.my
\end{abstract}

\begin{abstract}
Vocabulary size is believed to have positive correlations with learners' language skills, reading comprehension, knowledge acquisition, and academic achievement. In Malaysia, the lack of vocabulary has been identified as one of the causes for students' inability to acquire a second language. This quasi-experimental study examined the efficacies of employing the Contextualized Word Family (CWF) Model for direct vocabulary instruction (DVI) on vocabulary size and writing skills among secondary school students based on three proficiency levels. Through a purposive sampling method, 143 Grade 8 students were classified into three proficiency groups and were administered a similar treatment of contextualized word families. The Productive Vocabulary Level Test (PVLT) was used to measure the participants' vocabulary size and guided essay writing tests were employed to obtain their test scores in the pre-test and post-test. The findings revealed the positive effects of using the CWF Model for enhancing students' vocabulary size and writing ability. After a ten-week intervention, the majority of the students from low, intermediate, and high proficiency groups were able to increase their vocabulary size from below 1000 words to $1000-2000$ words. There was also an increase in the number of students who were able to reach the 2000 -word level of vocabulary size for all three groups. The findings from this study ascertained the positive effects of using the CWF Model to boost not only the vocabulary size, but also the writing skills of the high and intermediate proficiency students. On the writing tests, the high proficiency students showed a significant increase while the intermediate proficiency students experienced a slight increase in their writing test scores, but it was insignificant. Surprisingly, the low proficiency students experienced a significant decrease in their writing test scores after the treatment despite experiencing an increase in their vocabulary size. Future studies are recommended to utilize a true experimental design with a longer treatment period especially for examining the efficacies of the model on students' writing skills.
\end{abstract}

Keywords: vocabulary acquisition, vocabulary knowledge, contextualized word families, vocabulary size, explicit vocabulary instruction

\section{Introduction}

Vocabulary knowledge plays an essential role in literacy development and academic success. It supports the mastering of reading, speaking, listening, and writing skills (Al-Khasawneh, 2019; Silsüpür, 2017). Scholars have acknowledged the importance of vocabulary in second language (L2) learning and language use. In fact, past studies (e.g., August, Carlo, Dressler, \& Snow, 2005; National Reading Panel, 2000; Tosuncuoğlu, 2015) claim that vocabulary acquisition is vital for language learning because vocabulary encompasses all the lexical items language learners need to know in order to access their schemata, express ideas, communicate effectively, and learn about new concepts (Sedita, 2005). Moreover, there is a strong relationship between learners' vocabulary knowledge and their reading comprehension and future reading success (Cunningham \& Stanovich, 1997; Senechal, Oulette, \& Rodney, 2006; Xie et. al. 2019). Therefore, teachers are encouraged to train students to model an explicit vocabulary learning strategy to boost vocabulary acquisition. However, previous studies on vocabulary learning and acquisition had not come to a definite finding for an effective strategy or a structured, 
direct form of vocabulary instruction. Hence, this quasi-experimental research aims to examine the efficacies of administering direct vocabulary instruction (DVI) by employing the Contextualized Word Family (CWF) Model (Subon, 2016) on the learners' vocabulary size and writing ability.

This study utilizes the CWF Model (Subon, 2016) as a strategy for explicit vocabulary instruction. There are two main rationales for employing this model. First, it consists of eight pertinent principles for effective DVI: giving definitions of the new words, teaching vocabulary in context, teaching tier-two words, teaching vocabulary in word families, using non-linguistic representation/symbols/pictures, providing multiple exposures, using sentences that construct a story, and integrating vocabulary learning and the acquisition of word families with contexts and a variety of language learning activities (Subon, 2018). Unlike other vocabulary instruction models in the past, e.g., the Frayer Model (Frayer, Frederick, \& Kalausmeier, 1969), Grave's Visionary Model (Grave, 2000), and the STAR Model (Blachowicz, 2005) that utilize individual word in their vocabulary learning, the CWF Model (Subon, 2016) emphasizes learning words by groupings, or what is commonly known as word families.Secondly, the CWF Model exemplifies rich, systematic, and structured vocabulary instruction that integrates vocabulary learning with contexts. This is to enable learners to understand the meaning of a word more effectively by embedding it within a rich context of supportive and indicative information (Stahl \& Fairbanks, 1986). The word family members of this model are adapted from Bauer \& Nation's (1993) level 2 (inflectional suffixes) words. They are formed based on the different parts of speech, namely the base or plural verbs (teach), singular verbs (teaches), the past tense (taught), past participles (taught), nouns (teacher), adjectives (teachable), and present participles (teaching). The CWF Model consists of seven steps for teaching and learning a word family, as shown in Table 1 and Figure 1.

For this study, the three research questions are: 1) Does direct vocabulary instruction using the CWF Model increase learners' vocabulary size? 2) Does direct vocabulary instruction using the CWF Model result in significant difference in learners' writing ability? and 3) Is there any positive correlation between learners' vocabulary size and writing scores after direct vocabulary instruction using the CWF Model? This study also seeks to test one hypothesis (Hypothesis 1): There is a positive correlation between learners' vocabulary size and writing scores after the direct vocabulary instruction using the CWF Model.

\section{Problem Statement}

The lack of vocabulary has been identified as one of the factors contributing to learners' inability to acquire L2 (Kaur \& Kabilan, 2007; Kaur, Othman, \& Abdullah, 2012; Zakaria, 2005). In English deficit environments such as Malaysian schools, the issue of low language proficiency is still prevalent because of an underlying factor associated with vocabulary size. Although the apparent lack of proficiency among L2 leaners has been corroborated with a paucity of systematic, intentional vocabulary teaching and learning for ESL learners (e.g., Biemiller, 2005; Durkin, 1979; Dutro \& Moran, 2003; Gersten \& Baker, 2000; Moore, 2010; Scarcella, 1996; Scott \& Nagy, 1997), there have been relatively few studies on explicit vocabulary instruction using word families (Nadarajan, 2009; Schmitt, 2008). Although some studies have been conducted on DVI, these past studies usually focused on learning vocabulary as individual words or teaching words in isolation. Furthermore, limited studies on DVI have been conducted among early middle school students between the age of 12-14 years old (Mast, 2011), as well as among young learners at the elementary level. Hence, this study was conducted to explore new and effective strategies for vocabulary intervention in L2 classrooms.

\section{Literature Review}

Acquiring an ample vocabulary size is important for learners to be competent in English as a second (ESL) or foreign language (EFL). Although there exists a dire need to increase learners' vocabulary size for English proficiency, limited research has been carried out on ways to increase learners' vocabulary size in Malaysia (Haris \& Yunus, 2018). More empirical data are needed on learners' vocabulary size for educators and practitioners to address limitations in second language acquisition (SLA). Studies by Asgari and Mustapha $(2011 ; 2012)$ and Haris and Yunus (2018) suggest that a limited vocabulary size affects the acquisition of English as an L2. When learners are actively acquiring new words through various learning experiences, e.g., engaging with reading texts in the teaching and learning activities, they will be able to increase their vocabulary size. Hence, L2 classrooms should include explicit vocabulary learning for students to receive the comprehensible 
input of new vocabulary words. Arguably, the gradual increase in vocabulary size can enhance the breadth and depth of lexical knowledge, as well as proficiency in ESL.

A positive relationship between vocabulary size and language skills has also been supported by past studies (e.g., Albrechtsen, Haastrup, \& Henriksen, 2008; Alderson, 2005; Laufer, 1992; Laufer \& Goldstein, 2004; Laufer \& Sim, 1985).According to Laufer and Sim (1985) and Qian (2002), vocabulary size is an important prerequisite for learners to function as an efficient reader and achieve success in the academic field (as cited in Tschirner, 2004). While some scholars (Albrechtsen, Haastrup, \& Henriksen, 2008; Laufer, 1992; Laufer \& Goldstein, 2004) corroborated a close relationship between vocabulary size and reading, Alderson (2005) ascertained a strong relationship with other language skills such as reading, writing, listening, and grammar. Hence, "language ability is, to quite a large extent, a function of vocabulary size' (ibid. p. 88). Additionally, learners need to possess an ample vocabulary in terms of word families to perform well in all language skills (Schmitt, 2008; Waring, 2002). A 'word family' is a group of words that share the same basic meaning. For example, 'succeed' is in the same word family as success, succeeds, succeeding, succeeded, successful, and successfully. For reading and writing, learners will need 3,000-word families for reading authentic texts (Schmitt, 2007) and a minimum of 5,000-word families is required for the purpose of deeper processing (Thornbury, 2002). Spoken discourse requires a lower threshold of vocabulary i.e., 2,000-word families to cover about $95 \%$ of a typical speech (Adolphs \& Schmitt, 2003). On that note, L2 learners need a minimal vocabulary size of 2,000 high-frequency words to understand about $80 \%$ of a running text (Nemati, 2010). Therefore, an ample vocabulary size is vital for ESL learners to be proficient speakers or users of the L2.

However, there are limited studies on the effects of vocabulary instruction on students' writing skills. Some of these past studies (e.g., Duin \& Graves, 1987; Hestad, 2014; Solati-Dehkordi \& Salehi, 2016; Yonek, 2008) revealed some positive findings. Duin and Graves (1987) examined the effects of teaching vocabulary during pre-writing on students' writing quality. They found a significant increase in the number of target words used in writing, the overall quality of the writing, and on measures of vocabulary knowledge. They concluded that teachers could help students improve the quality of their writing by administering rich vocabulary instruction. Yonek's (2008) study supports the finding by Duin and Graves (1987) that rich instruction is more effective for increasing students' word knowledge. As a matter of fact, explicit vocabulary instruction allows learners to utilize newly learned words in complex literacy skills such as writing.

Additionally, Hestad (2014) conducted a study to evaluate the effects of targeted vocabulary instruction on writing fluency. He found that vigorous vocabulary instruction can improve writing fluency. By using a reading comprehension activity and explicit vocabulary instruction, Solati-Dehkordi and Salehi (2016) examined the effects of vocabulary instruction on L2 learners' writing skills and vocabulary retention. They concluded that explicit vocabulary instruction followed by an immediate writing task enabled the newly learned words to become productive vocabulary and allowed for enhanced vocabulary retention. Considering the importance of possessing an ample vocabulary size, this study offers a systematic, structured, and rich vocabulary instruction method for L2 learners in the Malaysian context, which employs the CWF Model (Subon, 2016) of DVI to examine the efficacies on students' vocabulary size and writing skills.

\section{Materials and Methods}

\section{Research Design}

This study employed a quasi-experimental design without any control group because the research was conducted under normal school conditions whereby the students remained in their own classrooms during the treatment period. Furthermore, the use of this design was to avoid disrupting the school's on-going programs such as extra-curricular activities. Since it was conducted under normal conditions in a natural setting, this design was more likely to have external validity (Seliger \& Shohamy, 2008).

\section{Participants}

The participants were selected from a rural secondary school in Sarawak, Malaysia. A purposive sampling method was used to select 143 Grade 8 students from four classes.They were classified into three proficiency 
groups (High, Intermediate, and Low) based on the grades they obtained in the English subject on the school examination that tested reading and writing skills. This examination paper that is usually prepared following the format for lower secondary public examination determines their proficiency levels. Based on this examination, students who scored $80-100 \%$ were classified as the High Proficiency Group (42 students), those who obtained 60-79\% formed the Intermediate Proficiency Group (58 students), and the Low Proficiency Group comprised of those who scored 35-59\% (43 students). Since the same group was used for both the pre-test and the post-test, it was not necessary to match one group to another (Seliger \& Shohamy, 2008).

\section{Data Collection Methods}

A quantitative method was used for the data collection. First, Laufer and Nation's (1999) Productive Vocabulary Levels (PVLT) Test ${ }^{1}$ was adopted and administered in the pre-test and post-test to measure the students' vocabulary size. This test has been proven to be a reliable measure of vocabulary levels (Zimmerman, 2005). In this study, the vocabulary tests measured the 2000 -word level for both the pre-test and the post-test. This word level contains the high-frequency words that all learners need to acquire in order to function effectively in English (Nation, 1990). The PVLT or a Check list test are ways to estimate vocabulary size that require learners to mark the words on a list that they believe they know (Hunt \& Beglar, 1998). For example: Teenagers often adm _ a and worship pop singers. Each of the PVLTs consisted of 18 items. A score of $83 \%$ shows that a student has reached the 2000-word level for the vocabulary tests as specified by Laufer and Nation (1999). The test scores were rated in percentages and computed using SPSS version 22.0 for the data analysis.

The second assessment measured the effects of explicit instruction using the CWF Model on students' writing skills. Students were required to write a guided essay of not less than 120 words before (pre-test) and after (post-test) the treatment. The tests followed the format of guided essay writing for Grade 8 students, with short notes provided for the given topics. Some of the words included in the notes were the words that they had learnt using the CWF Model during the intervention. They were required to expand the notes into an essay of about 120 words. The generic analytic scale i.e., the ESL Composition Profile (Jacobs et al., 1981) was used to rate the essays. The scale consists of five ESL writing sub-constructs and each sub-scale carries a different weight: content is given the highest weight (30\%), language use, organisation, and vocabulary have moderate weights $(25 \%, 20 \%$, and $20 \%$ respectively), while mechanics was the lowest $(5 \%)$. The students' final scores on the pre-test and post-test were determined by averaging the scores awarded by the two raters. Finally, these average scores were computed using SPSS version 22.0 for the data analysis.

\section{Data Collection Procedures}

The English teachers who taught the four classes accepted the informed consent on the confidentiality of their involvement in the research. The four teachers have more than ten years of teaching experience and they agreed to participate in the research by administering the explicit vocabulary instruction.In order to ensure a smooth implementation of the vocabulary intervention, they were briefed on the seven steps for conducting the direct vocabulary instruction using the CWF Model during their English lessons by adhering to the fixed schedule. They were provided with a pocket file that contained the necessary instructional materials such as the research study schedule, glossary of tier-two target words and definitions, list of word families, samples of entries of the contextualized word families, and a scripted lesson plan (the steps for conducting the direct vocabulary instruction using the Contextualized Word Family Model). Informed consent was also obtained from the students' parents of the four classes to allow their children to participate in the research and they were informed about the purpose of the research. The students involved were also briefed about the purpose of the research, their roles as respondents, and the confidentiality of their involvement.

Two experienced English teachers were also appointed as raters for the guided essay writing tests. They have more than 20 years of teaching experience in teaching the English language in schools. They rated the guided essay writing scripts using the rubrics provided i.e., the ESL Composition Profile (Jacobs et al., 1981). One rater has the qualification of a Bachelor of Education in Teaching English as a Second Language (TESL) and the other has a Bachelor of Human Resource Management, with a subject option for teaching English. Usually, two raters are employed to evaluate the same samples and if they failed to rate consistently, a third rater would evaluate the

\footnotetext{
${ }^{1}$ From “Productive Vocabulary Levels Test (PVLT)” by B. Laufer \& P. Nation (1999). http://www.lextutor.ca/tests/levels/productive/
} 
samples again (Hamp-Lyons, 1990). To measure the inter-rater reliability, Pearson product moment correlation was applied. The average values of the two raters' scores for the pre-test and post-test were used for the data analysis.

The vocabulary instruction was conducted over ten weeks. Four English teachers and four classes were involved in the study. All three proficiency groups remained in their own classrooms. Every group was given the same treatment using the CWF Model immediately after the pilot study. First, the pre-test using the PVLT 2000-word level (Test A) and the guided essay writing (Test 1) were administered a day before the treatment started. This was followed by explicit vocabulary instruction or the treatment using the CWF Model for ten weeks. The seven steps (Table 1) for the teaching and learning of word families using the CWF Model were followed very closely for the explicit instruction of contextualized word families in this quasi-experimental study.

Table 1

The seven steps of the Contextualized Word Family Model

1. Identifying a new tier-two word in a reading text

2. Giving a definition or meaning of the word

3. Listing the members of a word family

4. Constructing meaningful sentences using the members of the word family to show contexts

5. Writing a short paragraph using the members of the word family

6. Drawing a picture or symbol (non-linguistic representation) of the word family based on its common meaning or base form

7. Talking to friends about a completed entry of a word family

Note. Adapted from "The Contextualized Word Family Model of Direct Vocabulary Instruction" by F. Subon, 2018, IOSR Journal of Humanities and Social Science, 23, 57-70. Copyright 2016 by Frankie Subon.

During the treatment period, 30 sets of word families were taught to all three groups of learners, and the teaching and learning process took 30-35 minutes per lesson. The word families were from 30 tier-two words that were selected from reading texts used in the Grade 8 English textbook. Tier two consists of high-frequency words that are used across a variety of domains and are more characteristic of written language. They can be found across a variety of contexts and topics and understanding the meanings of these words promotes everyday reading and listening comprehension (Beck \& McKeown, 1985). Besides that, these words carry multiple meanings and are often used in mature language discourse such as in adult conversations and literature. Tier-two words are the most significant words for direct instruction (Hutton, 2008) because they are good measures of a student's progress through school. Beck and her colleagues suggest teachers give the direct instruction of tier-two words to add productively to learner's language ability. Examples of tier-two words include obvious, fortunate, complex, measure, industrious, and establish. In English, there are about 7,000word families (or 700 per year) in tier two (Hutton, 2008).

For this study, the tier-two words used in the intervention included conserve, guide, participate, develop, investigate, educate, etc. Students were given a pocket file equipped with a research study schedule, a checklist of tier-two target words, a sample of a completed entry of the contextualized word family (Figure 2), and 30 blank graphic organizers of the CWF Model on A4 paper. For each lesson, students were required to complete one graphic organizer (Figure 1) of the CWF Model (which consists of seven segments based on the seven steps of the model) and they were encouraged to use a dictionary when necessary. After the last session of the treatment, the post-test was administered using both instruments; PVLT 2000-word Level (Test B) and a guided essay writing test (Test 2). 
Figure 1

The Contextualized Word Family Model of Direct Vocabulary Instruction.

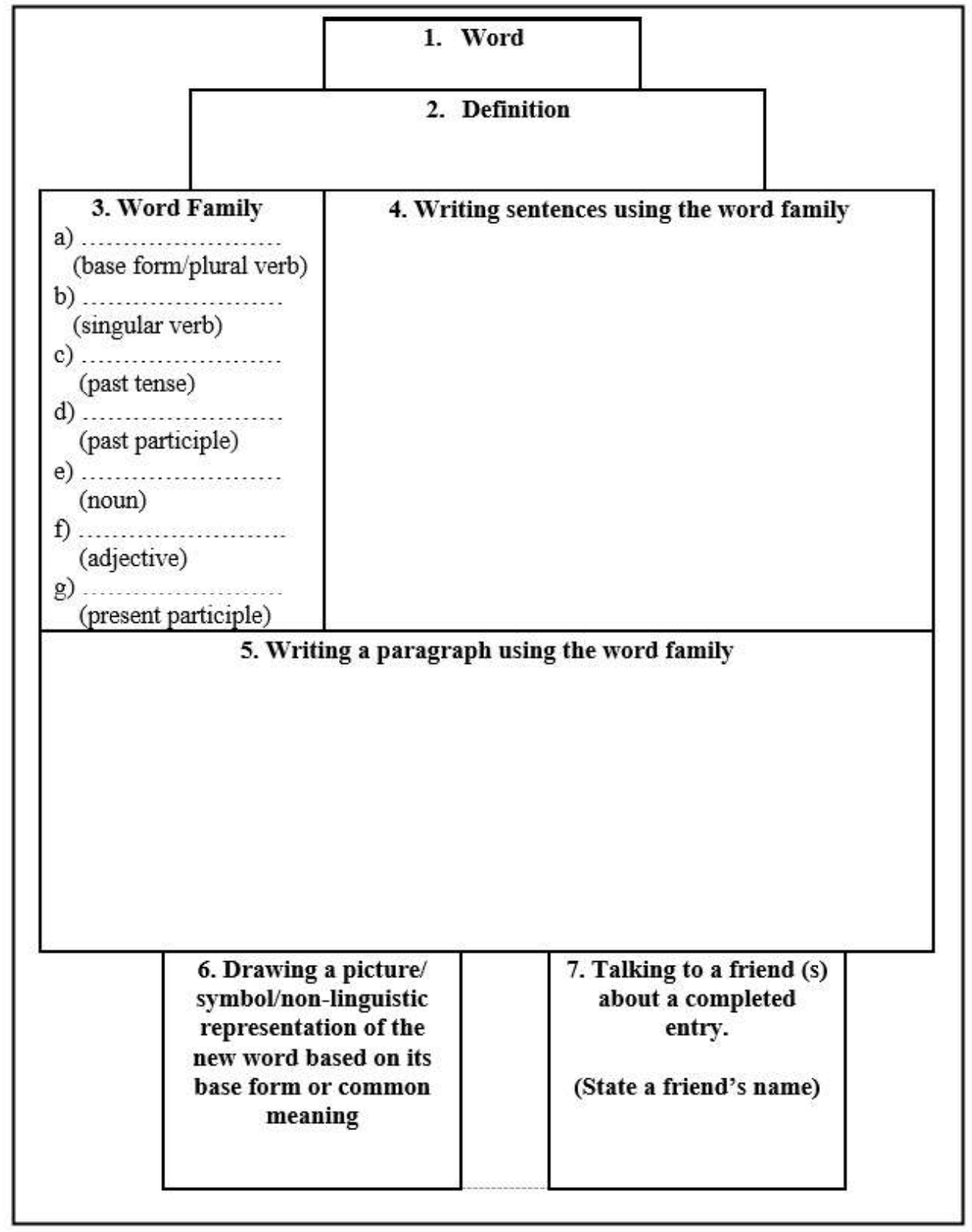

Note. From "The Contextualized Word Family Model of Direct Vocabulary Instruction" by F. Subon, 2018, IOSR Journal of Humanities and Social Science (IOSR-JHSS), 23, 57-70. Copyright 2016 Frankie Subon 
Figure 2

An example of a completed entry of the Contextualized Word Family

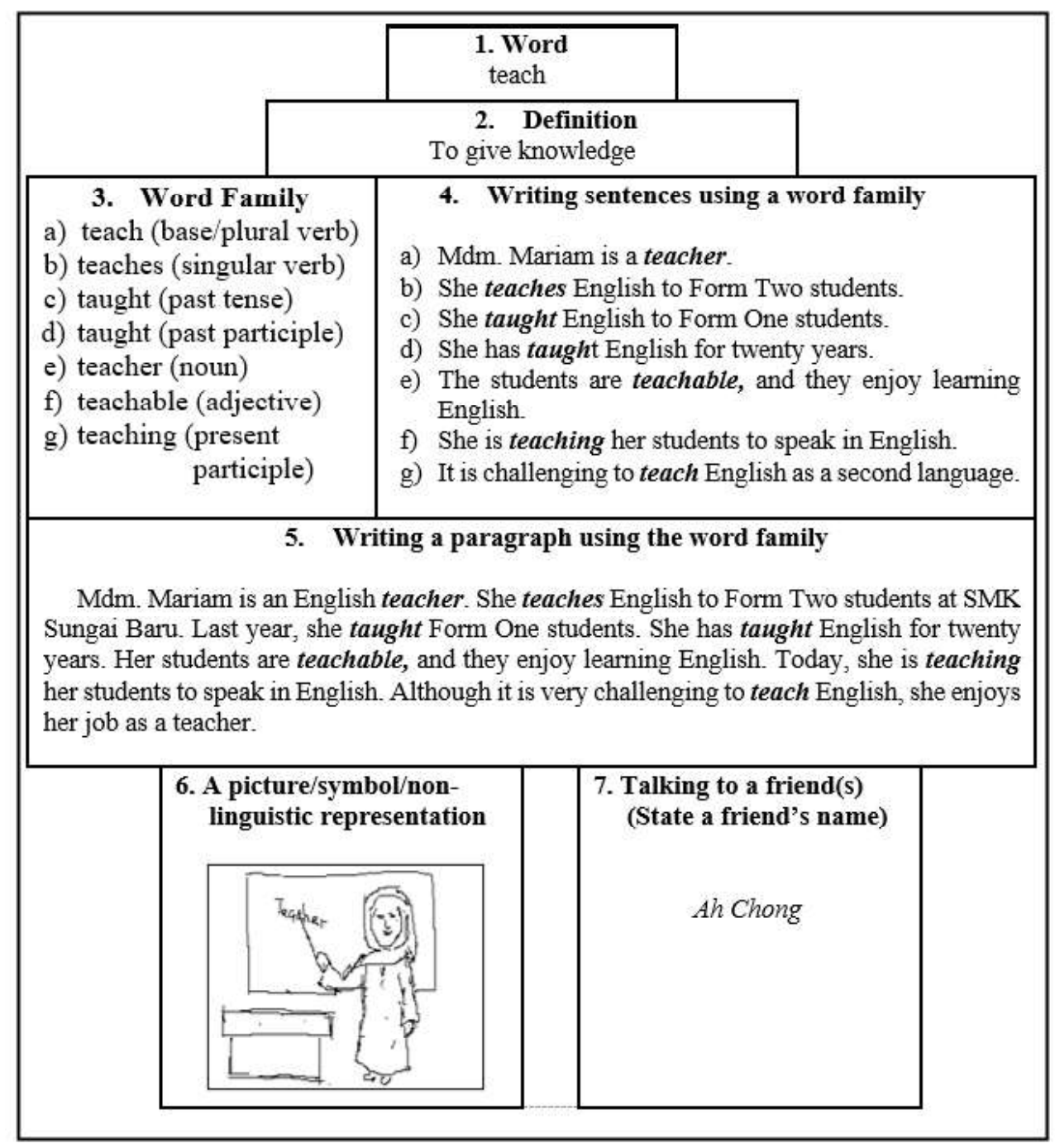

Note. From "The Contextualized Word Family Model of Direct Vocabulary Instruction" by F. Subon, 2018, IOSR Journal of Humanities and Social Science, 23, 57-70. Copyright 2016 Frankie Subon

\section{Data Analysis}

The data obtained from the pre-test and post-test scores were coded for statistical analysis to respond to the research questions. For Research Question 1, descriptive statistics for frequencies were applied to obtain patterns for Productive Vocabulary Levels Test (PVLT) scores (both pre-test and post-test) to measure the vocabulary size based on proficiency levels. For Questions 2, inferential statistics (paired samples t-tests) were computed to determine whether there were significant differences in the writing test scores before and after direct instruction using the CWF Model. The paired samples t-test is used based on Chua's (2013) explanation that this test is used when two sets of data are obtained from the same subject group (one sample). Pearson correlation coefficients were run to answer Research Question 3 on whether there was a positive correlation between vocabulary size and writing scores after the treatment. The data obtained from the statistical analyses were tabulated and significant changes were analysed to generate the results of the study. 


\section{Results}

\section{Vocabulary Size based on Proficiency Levels}

A minimum score to master a 2000 -word vocabulary level is 15 out of 18 correct words or $83.3 \%$, which is equivalent to 1670 words (Laufer \& Nation, 1999). The data obtained from the pre-test and post-test were analysed using descriptive statistics i.e., frequency to show the students' vocabulary size according to their proficiency levels.

\section{Vocabulary Size of the HIGH Proficiency Group}

There were 42 students in the High Proficiency Group. Table 2 below shows the frequencies of the vocabulary scores on the pre-test and post-test.

Table 2

Frequencies of the High Proficiency Group's PVLT 2000-word level pre-test \& post-test scores/vocabulary size

\begin{tabular}{lcccc}
\hline \multicolumn{1}{c}{$\begin{array}{c}\text { Test Score (\%)/Vocabulary } \\
\text { Size }\end{array}$} & $\begin{array}{c}\text { Frequency } \\
\text { (Pre-Test) }\end{array}$ & $\begin{array}{c}\text { Percent } \\
\text { (Pre-Test) }\end{array}$ & $\begin{array}{c}\text { Frequency } \\
\text { (Post-Test) }\end{array}$ & $\begin{array}{c}\text { Percent } \\
\text { (Post-Test) }\end{array}$ \\
\hline $1(0-<25 \% / 0-<500)$ & 1 & 2.4 & 0 & 0 \\
$2(25-<50 \% / 500-<1000)$ & 10 & 23.8 & 2 & 4.8 \\
$3(50-<75 \% / 1000-<1500)$ & 15 & 35.7 & 16 & 38.1 \\
$4(75-<83.3 \% / 1500-<2000)$ & 8 & 19.0 & 3 & 7.1 \\
$5(83.3-100 \% /$ Mastered 2000) & 8 & 19.0 & 21 & 50.0 \\
\hline Total & $\mathbf{4 2}$ & $\mathbf{1 0 0 . 0}$ & $\mathbf{4 2}$ & $\mathbf{1 0 0 . 0}$ \\
\hline
\end{tabular}

Half of the students in the High Proficiency Group were able to gain mastery of the PVLT 2000-word level after the treatment. The students had experienced positive vocabulary growth and many had mastered the PVLT 2000-word level after the direct instruction. The findings showed that the High Proficiency Group had achieved a marked increase in vocabulary size after the direct instruction as 21 out of 42 (50\%) students had mastered the PVLT 2000-word level.

\section{Vocabulary Size of the INTERMEDIATE Proficiency Group}

The Intermediate Proficiency Group was made up of 58 students. Table 3 below shows the descriptive statistics of the PVLT pre-test and post-test scores of the Intermediate Proficiency Group.

Table 3

Frequencies of the Intermediate Proficiency Group's PVLT 2000-word level pre-test \& post-test scores/vocabulary size

\begin{tabular}{lcccc}
\hline $\begin{array}{c}\text { Test Score (\%)/ } \\
\text { Vocabulary } \\
\text { Size }\end{array}$ & $\begin{array}{c}\text { Frequency } \\
\text { (Pre-Test) }\end{array}$ & $\begin{array}{c}\text { Percent } \\
\text { (Pre-Test) }\end{array}$ & $\begin{array}{c}\text { Frequency } \\
\text { (Post-Test) }\end{array}$ & $\begin{array}{c}\text { Percent } \\
\text { (Post-Test) }\end{array}$ \\
\hline $1(0-<25 \% / 0-<500)$ & 5 & 8.6 & 2 & 3.4 \\
$2(25-<50 \% / 500-<1000)$ & 29 & 50.0 & 10 & 17.2 \\
$3(50-<75 \% / 1000-<1500)$ & 23 & 39.7 & 32 & 55.2 \\
$4(75-<83.3 \% / 1500-<2000)$ & 1 & 1.7 & 6 & 10.3 \\
$5(83.3-100 \% /$ Mastered 2000$)$ & 0 & 0 & 8 & 13.8 \\
\hline Total & $\mathbf{5 8}$ & $\mathbf{5 0 . 0}$ & $\mathbf{5 8}$ & $\mathbf{1 0 0 . 0}$ \\
\hline
\end{tabular}

Table 3 shows that more students from the Intermediate Proficiency Group were able to obtain a vocabulary of between 1000 and 2000 words after the explicit vocabulary instruction and eight students were able to master the 2000-word level. 
The Vocabulary Size of the LOW Proficiency Group

There were 43 students in the Low Proficiency Group. The descriptive statistics (Table 4) show the frequencies of the Low Proficiency Group's vocabulary scores on the pre-test and post-test.

Table 4

Frequencies of the Low Proficiency Group's PVLT 2000-word level pre-test \& post-test scores/vocabulary size

\begin{tabular}{lcccc}
\hline $\begin{array}{c}\text { Test Score (\%)/Vocabulary } \\
\text { Size }\end{array}$ & $\begin{array}{c}\text { Frequency } \\
\text { (Pre-Test) }\end{array}$ & $\begin{array}{c}\text { Percent } \\
\text { (Pre-Test) }\end{array}$ & $\begin{array}{c}\text { Frequency } \\
\text { (Post-Test) }\end{array}$ & $\begin{array}{c}\text { Percent (Post- } \\
\text { Test) }\end{array}$ \\
\hline $1(0-<25 \% / 0-<500)$ & 17 & 39.5 & 11 & 25.6 \\
$2(25-<50 \% / 500-<1000)$ & 17 & 39.5 & 12 & 27.9 \\
$3(50-<75 \% / 1000-<1500)$ & 7 & 16.3 & 14 & 32.6 \\
$4(75-<83.3 \% / 1500-<2000)$ & 1 & 2.3 & 3 & 7.0 \\
$5(83.3-100 \% /$ (Mastered 2000) & 1 & 2.3 & 3 & 7.0 \\
\hline \multicolumn{1}{c}{ Total } & $\mathbf{4 3}$ & $\mathbf{1 0 0 . 0}$ & $\mathbf{4 3}$ & $\mathbf{1 0 0 . 0}$ \\
\hline
\end{tabular}

Table 4 above shows the low proficiency group of learners who had successfully increased their vocabulary size and the three students who had mastered the 2000-word level after direct instruction with the CWF Model.

\section{The Writing Test Scores based on Proficiency Levels}

In order to measure the inter-rater reliability, Pearson correlation coefficients were run for both the pre-test and post-test guided essay writing scores of the two raters. The inter-rater reliability coefficient was .83 for the pre-test scores and .86 for the post-test scores, implying a good level of reliability. Next, paired samples t-tests were computed to identify whether there were any significant differences in the writing skill test scores after the treatment of direct instruction using the CWF Model. The results of the data analyses for the three proficiency groups shown below.

\section{The Writing Test Scores of the HIGH Proficiency Group}

The paired-samples t-test for the High Proficiency Group's guided essay writing test scores is presented in Table 5.

Table 5

Paired samples t-test of the High Proficiency Group's guided essay writing test scores

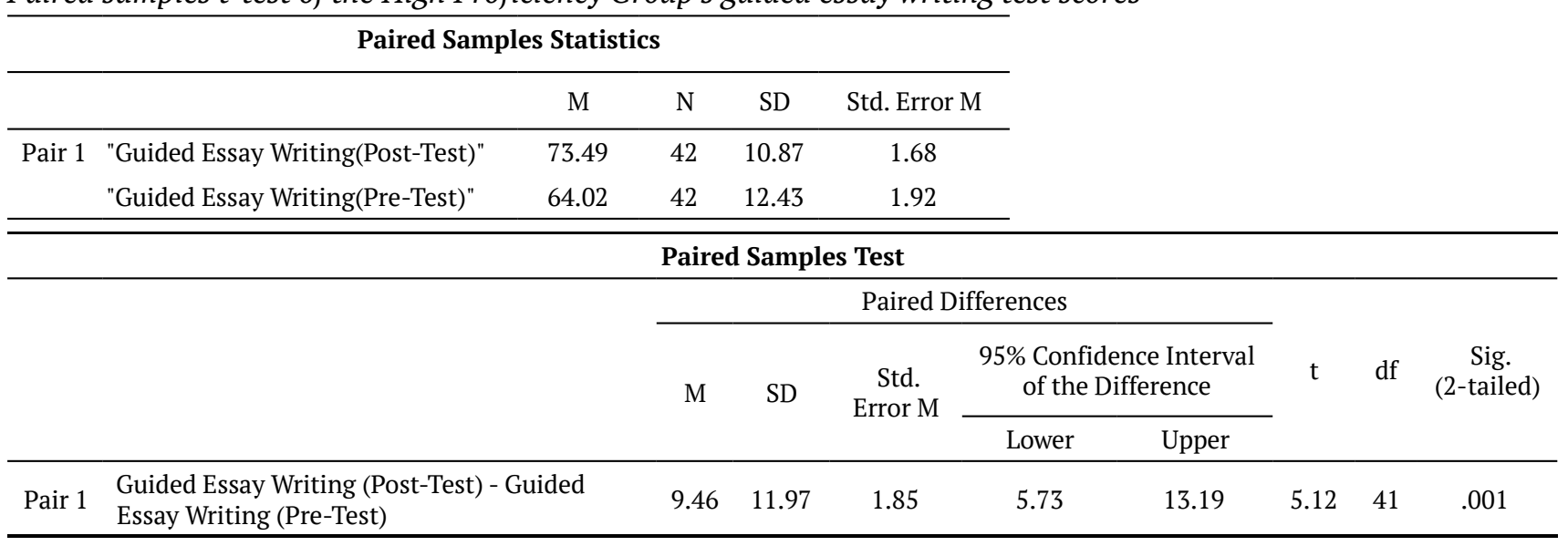

Students from the High Proficiency Group were able to increase their test scores for guided essay writing on the post-test. After the treatment through direct instruction using the CWF Model, the mean and standard deviation $(M=73.49, S D=10.87)$ were better than before the treatment on the pre-test $(M=64.02, S D=12.43)$. There was a statistically significant mean increase of 9.47, 95\% CI [5.73, 13.19], $t(41)=5.12, p=.001, d=.80$. There was also a statistically significant difference in the mean of the guided essay writing test scores after the direct instruction using the CWF Model with the High Proficiency Group. Moreover, the difference had a high practical significance as it had a large effect size of $d=.80$. 
The Writing Test Scores of the INTERMEDIATE Proficiency Group

The paired-samples t-test of Table 6 shows the mean difference between the pre-test and post-test of the guided essay writing test scores of the Intermediate Proficiency Group after direct instruction using the CWF Model.

Table 6

Paired samples t-test of the Intermediate Proficiency Group's essay writing test scores

\begin{tabular}{cccccc}
\hline \multicolumn{5}{c}{ Paired Samples Statistics } \\
\hline \multirow{2}{*}{ Pair 1} & M & N & SD & Std. Error M \\
& "Guided Essay Writing(Post-Test)" & 55.22 & 58 & 9.65 & 1.27 \\
& "Guided Essay Writing(Pre-Test)" & 52.97 & 58 & 9.53 & 1.25 \\
\hline
\end{tabular}

\begin{tabular}{|c|c|c|c|c|c|c|c|c|c|}
\hline \multicolumn{10}{|c|}{ Paired Samples Test } \\
\hline & & \multicolumn{5}{|c|}{ Paired Differences } & \multirow{3}{*}{$\mathrm{t}$} & \multirow{3}{*}{$\mathrm{df}$} & \multirow{3}{*}{$\begin{array}{c}\text { Sig. } \\
\text { (2-tailed) }\end{array}$} \\
\hline & & \multirow[t]{2}{*}{ M } & \multirow{2}{*}{ SD } & \multirow{2}{*}{$\begin{array}{l}\text { Std. } \\
\text { Error } \mathrm{M}\end{array}$} & \multicolumn{2}{|c|}{$\begin{array}{l}\text { 95\% Confidence Interval } \\
\text { of the Difference }\end{array}$} & & & \\
\hline & & & & & Lower & Upper & & & \\
\hline Pair 1 & $\begin{array}{l}\text { Guided Essay Writing (Post-Test) - Guided } \\
\text { Essay Writing (Pre-Test) }\end{array}$ & 2.25 & 11.93 & 1.57 & -.88 & 5.39 & 1.44 & 57 & .156 \\
\hline
\end{tabular}

The intermediate proficiency students were able to increase their guided essay writing test scores on the posttest. The post-test score after the treatment $(M=55.22, S D=9.65)$ was slightly better than before the treatment on the pre-test $(M=52.97, S D=9.53)$. There was a slight mean increase but not significant at $2.25,95 \%$ CI [-.88, 5.39], $t(57)=1.44, p=.156, d=.19$. This shows that there was no significant difference in the mean of the guided essay writing test scores after direct instruction using the CWF Model with the Intermediate Proficiency Group. However, the difference had low practical significance as it had an effect of $d=.19$, which did not meet the standard of even a small effect size (Cohen, 1988).

\section{The Writing Test Scores of the LOW Proficiency Group}

Table 7 below shows the paired samples t-test for the Low Proficiency Group after direct instruction using the CWF Model.

Table 7

Paired samples t-test of the Low Proficiency Group's essay writing test scores

\begin{tabular}{cccccc}
\hline \multicolumn{5}{c}{ Paired Samples Statistics } \\
\hline \multicolumn{2}{c}{ Pair 1 "Guided Essay Writing(Post-Test)" } & 44.85 & 43 & 8.39 & 1.28 \\
& "Guided Essay Writing(Pre-Test)" & 47.93 & 43 & 7.79 & 1.19 \\
\hline
\end{tabular}

Paired Samples Test

\begin{tabular}{|c|c|c|c|c|c|c|c|c|c|}
\hline & & \multicolumn{5}{|c|}{ Paired Differences } & \multirow{3}{*}{$\mathrm{t}$} & \multirow{3}{*}{$\mathrm{df}$} & \multirow{3}{*}{$\begin{array}{c}\text { Sig. } \\
\text { (2-tailed) }\end{array}$} \\
\hline & & \multirow{2}{*}{ M } & \multirow{2}{*}{ SD } & \multirow{2}{*}{$\begin{array}{c}\text { Std. } \\
\text { Error M }\end{array}$} & \multicolumn{2}{|c|}{$\begin{array}{l}\text { 95\% Confidence Interval } \\
\text { of the Difference }\end{array}$} & & & \\
\hline & & & & & Lower & Upper & & & \\
\hline Pair 1 & $\begin{array}{l}\text { Guided Essay Writing (Post-Test) - Guided } \\
\text { Essay Writing (Pre-Test) }\end{array}$ & -3.08 & 9.13 & 1.39 & -5.89 & -.27 & -2.21 & 42 & .032 \\
\hline
\end{tabular}

Students from the Low Proficiency Group showed a decrease in their guided essay test scores on the post-test after the treatment of direct instruction using the contextualized word families $(M=44.85, S D=8.39)$ than before the treatment on the pre-test $(M=47.93, S D=7.79)$, a statistically significant mean decrease of $-3.08,95 \% \mathrm{CI}$ $[-5.89,-.27], t(42)=-2.21, p=.032, d=.34$. This shows that there was a statistically significant difference in the mean of the guided essay test scores after direct instruction using the CWF Model with the Low Proficiency Group. However, the difference had low practical significance because it had a small effect size of $d=.34$. 


\section{The Correlation between Learners' Vocabulary Size and Writing Scores}

The Pearson correlation coefficients were run to determine whether there was a positive correlation between learners' vocabulary size and writing scores after the direct instruction using the CWF Model. The result of the data analysis showed that there was a moderate positive correlation between the two variables with $r=.53, p=$ .001. This reveals that when the vocabulary size increased the writing scores also increased. Therefore, we rejected the null hypothesis and accepted the alternative hypothesis (Hypothesis 1) that there was a positive correlation between learners' vocabulary size and writing scores after the direct vocabulary instruction using the CWF Model

\section{Discussion}

From the findings, it becomes clear that explicit vocabulary instruction using the CWF Model (Subon, 2016) had some positive effects on the vocabulary size of learners from all three proficiency groups. The descriptive analysis showed that they were able to demonstrate an increase in their vocabulary size ranging from 1000 to 2000 words after a ten-week intervention on the contextualized word families. There was also an increase in the number of participants who were able to master the 2000-word level after the intervention. The High proficiency group experienced a satisfactory increase in the mastery of the 2000 -word level from only eight out of 42 students on the pre-test to 21 students on the post-test while the Intermediate and the Low proficiency groups experienced a slight increase from none to eight out of 58 students and one to three out of 43 students respectively. Hence, this data confirms the findings from previous studies (e.g., Ghapanchi, Eskandari, \& Tabasi, 2012; Nadarajan, 2009; Naeimi \& Foo, 2015; Paribakht \& Wesche, 1997; Raasch, 2018; Schmitt, 2008; Soureshjani, 2011) that explicit vocabulary learning strategies have a significant effect on vocabulary acquisition of language learners. The findings are also consistent with past studies that showed teaching vocabulary in word families can lead to a greater growth in learners' vocabulary size (e.g., Beck \& Mckeown, 1991; Nadarajan, 2009; Schmitt, 2008; Schmitt \& Zimmerman, 2002; Soureshjani, 2011; The National Reading Panel, 2000). It has become more evident that the use of explicit vocabulary instruction enables learners to boost vocabulary growth as well as cultivate a productive habit for exploring word derivatives (Schmitt, 2000). Additionally, by employing word families for vocabulary instruction, this study sheds light on the potential of the CWF model for addressing the lack of structured vocabulary instruction, especially for increasing vocabulary size and improving writing skills among middle schoolers.

The findings also demonstrated some positive efficacies on learners' writing skills. A moderate positive correlation between learners' vocabulary size and writing scores was evident after the intervention with the CWF Model. The increase in the learners' vocabulary size after the treatment contributed to some positive effects on the learners' writing ability, especially among the high proficiency group. They showed an increase in the mean score after the treatment. The intermediate group also experienced a slight increase in the mean of their guided essay writing post-test scores after the treatment, although it was statistically insignificant. The increase in the marks for vocabulary, language use, and organization resulted in the increase in writing scores. This is consistent with the finding by Yonek (2008), who found that rich vocabulary instruction was more effective in the application of newly learned words to their expository writing than traditional instruction. This finding also ascertained that rich vocabulary instruction utilized (1) both definitional and contextual information for breadth of knowledge; (2) multiple exposures; and (3) active or deep processing of words (Beck, McKeown, \& Kucan, 2002; Stahl \& Fairbanks, 1986) was found to positively affect comprehension. After the intervention, students' writing skills also improved to a certain extent, as ascertained by an increase in their writing post-test scores. Thus, explicit vocabulary instruction using this model has shown to benefit learners' writing skills, especially among the high proficiency learners.

Consequently, this study revealed some fundamental implications. First, there is a pressing need for ESL learners to increase their vocabulary size, and this can be implemented by utilizing the CWF Model (Subon, 2016). Despite the positive increase in vocabulary size after the CWF intervention, the participants were still lacking the vocabulary needed to function well in the second language. Half ( 21 out of 42 students) of the High proficiency group and a big percentage ( $86.2 \%$ or 50 out of 58 students) of the Intermediate group, as well as 93\% (40 out of 43 students) of the Low proficiency groups still had a vocabulary size below the 2000 -word level after the ten weeks of treatment. Although the intermediate and low proficiency groups experienced a 
statistically significant mean increase in their vocabulary size, only a small percentage from these two groups were able to gain a mastery of the 2000-word level after the treatment. In view of this prevailing weakness in students' vocabulary sizes, there is a need to implement explicit vocabulary instruction that gives special attention to the low and intermediate proficiency learners. This finding resonates with the literature that recommends the explicit teaching of word meanings for struggling and average readers (Coyne et al., 2010; Stahl \& Fairbanks, 1986). Past studies also suggest that if students were taught in a way that positively supported their vocabulary growth, they would be able to clarify and enrich their understanding of the meanings of known words (Ilter, 2017, 2018). Through this vocabulary intervention program, learners can be purposefully trained to acquire at least the minimum significant level of vocabulary that they should possess i.e., 2,000-word families for typical speech (Adolphs \& Schmitt, 2003), 3,000-word families for reading authentic texts (Schmitt, 2007), and 5,000-word families for the purpose of deeper processing (Thornbury, 2002).

Despite its success, the efficacy of this CWF method for enhancing students' guided essay writing requires further investigation. Among the three proficiency groups, only the high proficiency group experienced a statistically significant difference, with an increase in the writing test scores mean after the intervention. There was no significant difference in the test scores after the treatment among the intermediate group, as there was only a slight increase in the mean test scores. On the other hand, the low proficiency group showed a statistically significant difference in their guided essay writing test scores after the intervention, but the results showed a decrease in the mean score. This implies that many of the learners, especially among the intermediate and low proficiency groups, were still unable to write well on the guided essay writing test. Most of them, especially among the low proficiency group, showed a decrease in scores for almost all aspects, including vocabulary, language use, organisation, and content. Hence, their lack of vocabulary was one of the reasons for their inability to obtain good scores for their guided essay writing on the post-test. Despite encouraging growth in the learners' vocabularies after the intervention, the findings also showed that the majority of the students still had a vocabulary size that was below the 2000 -word level, i.e., a minimum number of words students should possess to be competent in the target language. According to Nation and Waring (1997), learners need at least 2000 words to be able to obtain $80 \%$ text coverage for written discourse. This is consistent with the notion that the lack of vocabulary is often quoted as one of the main reasons for the lack of proficiency in English. This finding provides an important implication that secondary school teachers should help ESL learners develop their L2 productive skills. As suggested by Danilović Jeremić (2015), more emphasis should be paid to the development of productive lexical knowledge at the primary and secondary level of education, which is crucial not only for their future success in English degree courses but also to communicate well in English.

Another important implication is for ESL learners to be given multiple exposures to tier-two or high-frequency words. The CWF Model (Subon, 2016) provides up to seven exposures to the same word and the learning activities involve all four language skills of reading, writing, listening, and speaking. This notion of multiple exposures is supported by Stone and Urguhart (2008) who reiterate that learners should have ample opportunities of at least six encounters with words that are beneficial to learning a new content. Nation (1990) also recommends between five and 16 repetitions to learn a word. Seven or more repetitions are supported by Mckeown, Beck, Omanson, and Pople (1985), who reiterate that even a rich vocabulary program of instruction requires more encounters with a word.Teaching a new word only once is a big mistake because there is a high probability that the word will be forgotten (Schmitt, 2008). Additionally, tier-two words or academic words should be the major focus of vocabulary instruction (Mckeown \& Beck, 2011) for writing. It is essential to teach tier-two words (Mckeown \& Beck, 2011) or academic vocabulary (Nation, 2001) for the explicit vocabulary instruction of word families because they are used in various types of texts and the meaning they bring to a text (Nation, 2001). Welcome, measure, discover, advertisement, and threatens are some examples of the tier-two words used in this study. The rationale for selecting these words is that they are not only general words but are also high-utility words for literate language users.

This study also has its limitations. Firstly, the treatment of this study was only conducted for ten weeks, which was quite a short period of time for students to practise and improve their writing skills using this method. A longer period of time was not permissible, as students had school activities and holidays. Secondly, giving direct vocabulary instruction of tier-two words could have posed difficulties to the low proficiency group as they might not have acquired many basic vocabulary or tier-one words. The categories of words under tier one are sight words, nouns, verbs, adjectives, and early reading words. There are about 8,000-word families in 
English included in tier one. Furthermore, tier-two words are suitable for more advanced learners (Chung, 2012). We take for granted that native English speakers know most of the tier-one words, but this is not the case for L2 learners. Many tier-one words may be unknown to L2 learners and these words are essential for the comprehension of a passage and necessary for writing. Therefore, before giving direct instruction of tier-two or high-frequency words, L2 learners, especially the intermediate and low proficiency groups, need to be given direct instruction of tier-one or basic vocabulary, or both tiers of vocabulary.Giving them better exposure to not only new but the right vocabulary will allow for more impactful effects on their writing. Future research needs to take this factor into consideration when low proficiency students are among the study participants. Other limitations such as teachers' and learners' change in mood and interests during the treatment period were beyond the control of the researcher and beyond the scope of the present study. The instructors' teaching abilities might have led to different impacts on the students' performance due to different expectations, motivation, and attitudes.

\section{Conclusion}

This study has attempted to make fundamental contributions to vocabulary acquisition and second language acquisition research. Employing the CWF Model for explicit vocabulary instruction has revealed that teaching and learning vocabulary in word families can have a positive impact on learners' vocabulary size and writing skills. This seven-step explicit vocabulary instruction model, which involves a lot of repetition in learning word families, can help to reinforce learners' vocabulary depth and breadth. Therefore, teachers can adopt this model for enhancing learners' vocabulary acquisition and writing skills in ESL classrooms. Nevertheless, this quasiexperimental study is insufficient for determining the effects of this model fully on learners' vocabulary growth and writing skills due to its limitations. Further empirical research is essential to support and validate the efficacies of this model for enhancing ESL learners' vocabulary size and writing skills. Future studies may ascertain its effectiveness with different participants or participants from different contexts. For instance, studies can also be conducted among elementary school students or pre-university students in higher institutions by employing suitable tier words for their vocabulary learning and acquisition. In the coming months, we will conduct a fully experimental research study to verify and validate the efficacies of the CWF Model for enhancing ESL leaners' vocabulary growth, syntactical structures, and writing skills by making comparisons with other vocabulary learning strategies. This will enable us to employ participants for both control and the experimental groups. By comparing the performances between these two groups, we will be able to generate more compelling and reliable data to ascertain the findings of this future study.

\section{References}

Adolps, S., \& Schmitt, N. (2003). Lexical coverage of spoken discourse. Applied Linguistics, 24(4), 425-438. https:// doi.org/10.1093/applin/24.4.425

Albrechtsen, D., Haastrup, K., \& Henriksen, B. (2008). Vocabulary and writing in a first and second language: Processes and development. Palgrave Macmillan.

Alderson, J. C. (2005). Diagnosing foreign language proficiency. Continuum.

Al-Khasawneh, F. (2019). The impact of vocabulary knowledge on the reading comprehension of Saudi EFL learners. Journal of Language and Education, 5(3), 24-34. https://doi.org/10.17323/jle.2019.8822.

Asgari A., \& Mustapha, G. (2012). Vocabulary learning strategies of Malaysian ESL students. Pertanika Journal of Social Science \& Humanity, 20(3), 751-764.

Asgari, A., \& Mustapha, G. (2011). The type of vocabulary learning strategies used by ESL students in University Putra Malaysia. English Language Teaching, 4(2), 84-90. https://doi.org/10.5539/elt.v4n2p84

August, D., Carlo, M., Dressler, C., \& Snow, C. (2005). The critical role of vocabulary development for English Language learners. Learning Disabilities Research \& Practice, 20(1), 50-57. https://doi.org/10.1111/j.15405826.2005.00120.x

Bauer, L., \& Nation, I. S. P. (1993). Word families. International Journal of Lexicography, 6, 1-27.

Beck, I. L., \& McKeown, M. G. (1985). Teaching vocabulary: Making the instruction fit the goal. Educational Perspectives, 23(1), 11-15.

Beck, I. L., McKeown, M.G., \& Kucan, L. (2002). Bringing words to life; Robust vocabulary instruction. Guilford Press. 
Biemiller, A. (2005). Size and sequence in vocabulary development: Implications for choosing words for primary grade vocabulary instruction. In A. Hiebert \& M. Kamil (Ed.)., Teaching and learning vocabulary: Bringing research to practice (pp. 223-242). Erlbaum.

Blachowicz, C. L. Z. (2005). Vocabulary essentials: From research to practice for improved instruction. Scott Foresman and Co.

Chua, Y. P. (2013). Mastering research statistics. McGraw-Hill Education.

Chung, S. F. (2012). Research-based vocabulary instruction for English language learners. The Reading Matrix, 12(2), 105-120.

Cohen, A. D. (1988). Strategies in learning and using a second language. Longman.

Coyne, M., McCoach, B., Loftus, D., Zipoli, S., Ruby, R., Crevecoerut, Y., \& Kapp, S. (2010). Direct and extended vocabulary instruction in kindergarten: Investigating transfer effects. Journal of Research on Educational Effectiveness, 3, 93-120. https://doi.org/10.1080/19345741003592410

Cunningham, A.E., \& Stanovich, K. E. (1997) Early reading acquisition and its relation to reading experience and ability ten years later. Developmental Psychology, 33, 934-45. https://doi.org/10.1037//0012-1649.33.6.934

Danilović Jeremić, J. (2015). Lexical knowledge of Serbian L1 English L2 learners: Reception vs. production. Nastava i vaspitanje, 64(1), 87-100. https://doi.org/ 10.5937/nasvas1501087D

Duin, A.H., \& Graves, M. F. (1987). Intensive vocabulary instruction as a prewriting technique. Reading Research Quarterly, 22(3), 311-330. https://doi.org/10.2307/747971

Durkin, D. (1979). What classroom observation reveal about reading comprehension instruction. Reading Research Quarterly, 14, 481-538.

Dutro, S., \& Moran, C. (2003). Rethinking English language instruction: An architectural approach. In G. Garcia (Ed.), English learners: Reaching the highest level of English literacy (pp. 227-258). International Reading Association.

Frayer, D. A., Frederick, W. C., \& Kalausmeier, H. J. (1969). A schema for testing the level of concept mastery. Technical Report No. 16. University of Winconsin Research and Development Centre for Cognitive Learning.

Gersten, R., \& Baker, S. (2000). Effective instruction for English-language learners: What we know about effective instructional practices for English language learners. Exceptional Children, 66(4), 454-470. https:// doi.org/10.1177/001440290006600402

Ghapanchi, Z., Eskandari, Z., \& Tabasi, E. (2012). The effect of text-based direct vocabulary instruction on vocabulary acquisition. World Journal of English Language, 2(1), 74-80. https://doi.org/10.5430/wjel.v2n1p74

Graves, M. F. (2000). A vocabulary programme to compliment and bolster a middle grade comprehension programme. In B. M. Taylor, M. F. Graves, \& P. van den Broek (Eds.), Reading for meaning: Fostering comprehension in the middle grades (pp.116-135). International Reading Association.

Hamp-Lyons, L. (1990). Second language writing: Assessment issues. In B. Kroll (Ed.), Second language writing: Research insights for the classroom (pp. 69-87). Cambridge University Press.

Haris, M., \& Yunus, M. M. (2018). Vocabulary size of ESL IGCSE students. International Journal of Advance Research, 6(8), 263-267. https://doi.org/10.21474/IJAR01/7518

Hestad, L. C. (2014). The impact of vocabulary instruction on writing fluency [Unpublished doctoral dissertation]. Retrieved from ProQuest Dissertations and Theses. (UMI No. 3633490)

Hunt, A., \& Beglar, D. (1998). Current Research and Practice in Teaching Vocabulary. Japan Association for Language Teaching, 22(1), 7-11.

Hutton, T.L. (2008). Three tiers of vocabulary and education. https://www.superduperinc.com/handouts/pdf/182_v

İlter, I. (2017). Teaching word meanings to students at different reading ability: A controlled assessment of the contextual-based vocabulary instruction on reading comprehension. Education and Science, 42(190), 437463. https://doi.org/10.15390/EB.2017.6482

İlter, İ. (2018). Effects of the instruction in inferring meanings from context on the comprehension of middle school students at frustration reading level. Journal of Education, 198(3), 225-239. https://doi. org/10.1177/0022057418818818

Jacobs, H., Zingraf, S., Wormuth, D., Hartfiel, V.F., \& Hughey, J. (1981). Testing ESL composition: Apractical approach. Newbury House Publishers.

Kaur, N., \& Kabilan, M. K. (2007). Autonomy in ESL: To what extent? Paper presented at Literary Conference (LITCON) 2007, Penang, Malaysia.

Kaur, N. Othman, N. H., \& Abdullah, M. K. K. (2012). Lexical competence among tertiary students: Teacherstudent perspectives. The English Teacher, 37, 90-104.

Laufer, B. (1992). How much lexis is necessary for reading comprehension? In P. J. L. Arnaud \& H. e joint (Ed.). Vocabulary and applied linguistics (pp. 126-132). Macmillan. 
Laufer, B., \& Goldstein, Z. (2004). Testing vocabulary knowledge: Size, strength, and computer adaptiveness. Language Learning, 54(3), 399-436. https://doi.org/10.1111/j.0023-8333.2004.00260.x

Laufer, B., \& Sim, D. D. (1985). Measuring and explaining the reading threshold needed for English for academic purposes texts. Foreign Language Annals, 18(5), 405-411.https://doi.org/10.1111/j.1944-9720.1985.tb00973.x

Mast, D. W. (2011) Using semantic maps and word families in the beginning-level middle school foreign language classroom. A Journal for $K-16+$ Foreign Language Educators, 68(1), 63-70.

Mckeown, M. G., \& Beck, I. L. (2011). Making vocabulary interventions engaging and effective. In R. E. O'Connor, \& P. F. Vadasy, (Ed.), Handbook of reading interventions (pp. 138-168). New York: Guilford Press.

McKeown, M. G., Beck, I. L., Omanson, R. C., \& Pople, M. T. (1985). Some effects of the nature and frequency of vocabulary instruction on the knowledge and use of words. Reading research Quarterly, 20, 522-535. https:// doi.org/10.2307/747940

Moore, D. W. (2010). Direct Instruction: Targeted strategies for student success. http://www.insideng.com/profdev/ guides/Moore_Instruction.pdf

Nadarajan, S. (2009). The effect of instruction and context on L2 learners' vocabulary development. Electronic Journal of Foreign Language Teaching, 6(2), 177-189.

Naeimi, M., \& Foo, T. C. V. (2015). Vocabulary Acquisition through Direct and Indirect Learning Strategies. English Language Teaching, 8(10), 142-151. https://doi.org/10.5539/elt.v8n10p142

Nation, I. S. P. (1990). Teaching and learning vocabulary. Heinle \& Heinle Publishers.

Nation, I. S. P. (2001). Learning Vocabulary in another Language. Cambridge University Press.

Nation, P., \& Waring, R. (1997). Vocabulary size, text coverage and word lists. In Schmitt, N., \& McCarthy, M. (Eds.), Vocabulary: Description, acquisition and pedagogy (pp. 6-9). Cambridge University Press.

National Reading Panel (2000). Teaching children to read: An evidence-based assessment of the scientific literature on reading and its implications for reading instruction. National Institute of Child Health and Human Development.

Nemati, A. (2010). Proficiency and size of receptive vocabulary: Comparing EFL and ESL environments. International Journal of Educational Research and Technology, 1(1), 46-53.

Paribakht, T. S., \& Wesche, M. (1997). Vocabulary enhancement activities and reading for meaning in second language vocabulary development. In J. Coady \& T. Huckin (Ed.), Second language vocabulary acquisition: A rationale for pedagogy (pp.174-200). Cambridge University Press.

Qian, D. (2002). Investigating the relationship between vocabulary knowledge and academic reading performance: An assessment perspective. Language Learning, 52, 513-536. https://doi.org/10.1111/1467-9922.00193

Raasch, K. (2018). The Effects of Purposeful Vocabulary Instruction. https://sophia.stkate.edu/maed/274

Scarcella, R. C. (1996). Secondary education in California and second language research: Instructing ESL students in the 1990's. The CATESOL Journal, 9, 129-152.

Schmitt, N. (2008). Teaching vocabulary. White Ppains. Pearson Education.

Schmitt, N. (2007). Currentperspectivesonvocabulary teaching and learning. In J. Cummins, \& C. Davison (Eds.), International Handbooks of English Language Teaching (pp. 827-839). Springer.

Schmitt, N. (2000). Vocabulary in language teaching. Cambridge University Press.

Schmitt, N., \& Zimmerman, C. B. (2002). Derivative word forms: What do learners know? TESOL Quarterly, 36(2), 145-171. https://doi.org/10.2307/3588328

Scott, J. A., \& Nagy, W. E. (1997). Understanding the definitions of unfamiliar words. Reading Research Quarterly, $32,184-200$.

Sedita, J. (2005). Effective Vocabulary Instruction. Insights on Learning Disabilities, 2(1) 33-45.

Seliger, H. W., \& Shohamy, E. (2008). Second language research methods. Oxford University Press.

Senechel, M., Oulette, G., \& Rodney, D. (2006). The misunderstood giant: On the predictive role of early vocabulary to future reading. In D. K. Dickinson, \& S. B. Neuman (Eds.), Handbook of early literacy research (pp. 173-182). Guilford

Shostak, J. (2002) The value of direct and systematic vocabulary instruction. Professional development series, 7 , $1-11$.

Silsüpür, B. (2017). Does using language games affect vocabulary learning in EFL Classes? Journal of Foreign Language Education and Technology, 2(1), 83-104.

Solati-Dehkordi, S. A., \& Salehi, H. (2016). Impact of explicit vocabulary instruction on writing achievement of upper-intermediate EFL learners. International Education Studies, 9(4), 141-154. https://doi.org/10.5539/ies. v9n4p141

Soureshjani, K. H. (2011). The effects of contextualizing and decontextualizing techniques on lexical-oriented knowledge of Persian EFL language learners. Theory and Practice in Language Studies, 1(5), 547-552. https:// doi.org/10.4304/tpls.1.5.547-552 
Stahl, S. A., \& Fairbanks, M. (1986). The effects of vocabulary instruction: A model-based meta-analysis. Review of Educational Research, 56(1), 72-110. https://doi.org/10.3102/00346543056001072

Stone, B., \& Urquhart, V. (2008). Remove limits to learning with systematic vocabulary instruction. https://files.eric. ed.gov/fulltext/ED544614.pdf

Subon, F. (2016). Direct vocabulary instruction: The effects of contextualised word families on learners' vocabulary acquisition. Procedia - Social and Behavioral Sciences, 224, 284-291. https://doi.org/10.1016/j. sbspro.2016.05.461

Subon, F. (2018). The contextualized word family model of direct vocabulary instruction. IOSR Journal of Humanities and Social Science, 23, 57-70. https://doi.org/10.9790/0837-2303035770

Thornbury, S. (2002). How to teach vocabulary. Pearson Education Limited.

Tosuncuoğlu, İ. (2015). Teaching vocabulary through Sentences. Journal of History Culture and Art Research, 4(4), 1-11. https://doi.org/10.7596/taksad.v4i4.501.

Tschirner, E. (2004). Breadth of vocabulary and advanced English study: An empirical investigation. Electronic Journal of Foreign Language Teaching, 1(1), 27-39.

Waring, R. (2002). Why should we build up a start-up vocabulary quickly? http://www1.harenet.ne.jp/ waring/ vocab/principles/early.htm

Xie, R.,Zhang, J.,Wu, X., \& Nguyen, T. P. (2019). The relationship between morphological awareness and reading comprehension among Chinese children. Frontiers Psychology, 10, 1-13. https//doi.org/10.3389/ fpsyg.2019.00054

Yonek, L. M. (2008). The effects of rich vocabulary instruction on students' expository writing [Unpublished doctoral dissertation]. University of Pittsburgh. https://d-scholarship.pitt.edu/9995/1/yoneklisa122008.pdf

Zakaria, Z. (2005). Dictionary as tool in vocabulary acquisition for rural students [Unpublished master's dissertation], Universiti Sains Malaysia.

Zimmerman, K. (2005). Newly placed versus continuing students: Comparing vocabulary size. ESL Reporter, $38(1), 52-60$. 